UDC

\title{
油中放電図形と沿面放電に対する 細溝の効果
}

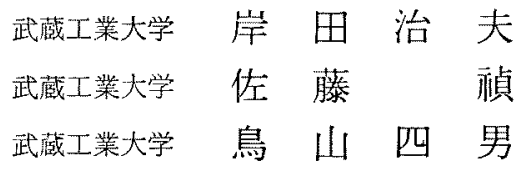

\section{1. まえがき}

絶縁油中に古る固体絶縁物の表面で発生する沿面放 電の性質は，主として写真乾板によるリヒテンベルグ 図形上，混合粉体在いる電荷図形 (Dust figure) (1)(2) $^{(2)}$ により研究されてきたが，これらは気体中の沿面放電 の場合に比べて手法上かなり難点がある。すなわち， リヒテンベルグ図形においては，現像を行なう前に暗 箱中において乾板に粘着した絶縁油を洗い落さなりれ ばならないし，図形から極性差を読み上るのも困難で ある。一方，電荷眓法は放電電荷の分布の極性を粉体 の色比よって知り元るという利点㤝あるが，粉体を散 布した後に絶緑板をガソリンなどで洗浄しなければ図 形が得ら机ず，図形を得る作業に相当熟練を要すると いう久点があ。

ところか最近，電子写真技術の発達，特化電子複 写機が急速に普及し，元机に使用される液体現像液 （トナ）市䨪荷に対する付着性，解像力が改良されて きた。著者らは，この現像液を利用し，簡単な操作て 酒中放電成形を得ることができたので，本論文では， この手法在用いて得られた残留霆荷の図形に上り沿面 放電の機㯕を説明し，さらに䋓縁板上に細满（slot）を 設けると，沿面放電の進展を阻止する効果があること がわかったので，本論文に柗いてての効果に対する检 討を行ない，問題の提起をする。

\footnotetext{
The Dischatge Figures in Insulating oil and the Effect of a Slot on Surface Discharge in Oil. By H. KISHIDA, Member, T. SATO, Member \& Y. TORIYAMA, Member (Department of Electrical Engineering, Musashi Institute of Technology).

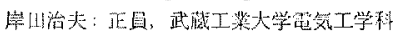

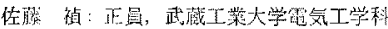

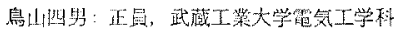

\section{2. 原理および方法}

放電図形は絶縁板上儿電荷が残留するとき現われ る。電荷の残留は絶縁板上淮体絶縁物の比誘電率招上 び絶縁抵抗に上り決定される。すなわち，絶緑板の 比誘電率が絶縁油のそ机より大であり，汃絶縁板と 絶縁油の絶縁抵抗が之屯に大きければ放電図形が得ら れる。

㬰験方法は絶縁油中に針対平板電極を配䈯し，両電 極間汇絶縁板（厚さ $3 \mathrm{~mm}$ のベークライト）をそう入 して針電極側に標準インパルス電圧を印加した。絶縁 油としては変压器油（2号）を用い，ガラスフィルタ (G3)による真空万過処理のみを行なった。放電図形 の現像方法の種類および過程は次のとおりである。

（1）正篦生を印加した場合は目極性トナを用い， 真電圧印加の場合には正極性卜ナを用いた。(以下， この現像法党順現像之呼ふ心）こ机汶対して，印加電圧 の極性之同極性のトナによる現像を行なった。(以 下，乙机を逆現像之呼引゙）

（2）電王を田加した後, 絶縁板を油中より取り出 して放電面化現像液を滴下するか，あるいは現像液中 に絶縁板を浸せきする。この場合の現像時間は約 20 秒である。

（3）現像を行なったのち石油采溶剂で洗浄する 上，板に付着した余分な卜ナが取り除加れ图形が現㕲 れる。こ礼らの作業比暗室操作は全く不要である。

\section{3. 実験結果と考察}

$\langle 3 \cdot 1\rangle$ 残留電荷と極性正図形々負図形の差異 は，第 1 図招よび第 2 図より明らかなように，順現像 をして得られた正図形に批いては負極性のトナ加付着 


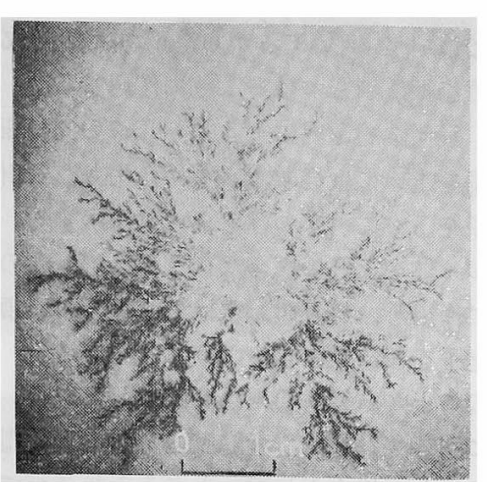

第 1 図 順現像による残留正䉓荷の図形 (正インパルス $60 \mathrm{kV}$ )

Fig. 1. Figure of positive residual charge by the forward development. (Positive impulse $60 \mathrm{kV}$ )

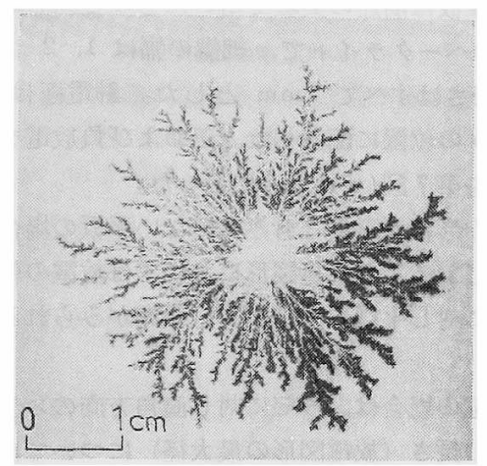

第 2 図順現像に上る残留負電荷の図形 (負インパルス $60 \mathrm{kV}$ )

Fig. 2. Figure of negative residual charge by the forward development. (Negative impulse $60 \mathrm{kV}$ )

するので，正電荷が残留し，その放電路の幅は負図形 より細いことがわかる。一方, 負図形においては放電 の幹 (Stem) の部分には正極性のトナが付着していな い。

これに対して逆現像をすると, 四加電圧が低い場合 の正図形ではほとんど図形が現わ机ないが，負図形に おいては放電路の中央に負極性のトナによる細い筋状 の図形が現わ机る。これは順現像をした負図形の正卜 ナが付着しなかった幹の部分に対応しているので, そ の部分には正電荷が残留していることがわかる。印加 電圧が高い場合には, 正負両放電ともに残留表面電荷 による逆放電 (Back discharge) の図形が中心部に現 わ机るのが, 第 3 図および第 4 図において観察され る。逆現像をした正図形において, 逆放電の図形以外

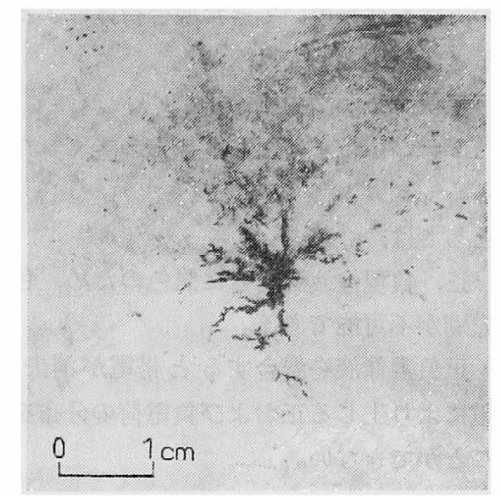

第 3 図 逆現像に上る正需圧印加時の残留 負電荷の図形 (インパルス $100 \mathrm{kV}$ )

Fig. 3. Figure of negative residual charge by the reverse development on applying positive voltage. (Impulse $100 \mathrm{kV}$ )

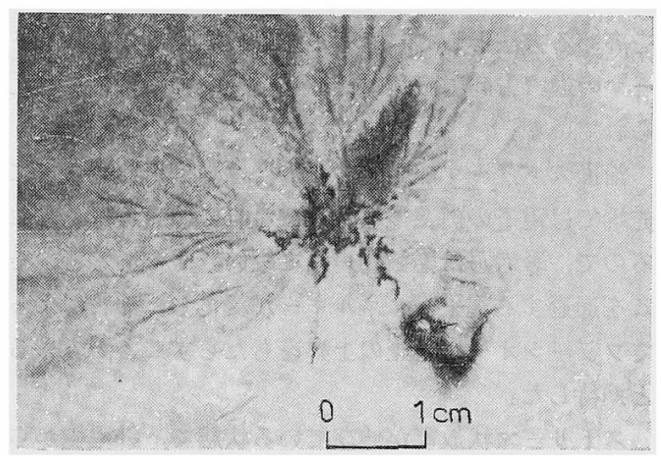

第 4 図 逆現像に上る負電圧印加時の残留 正電荷の図形 (インパルス $100 \mathrm{kV}$ )

Fig. 4. Figure of positive residual charge by the reverse development on applying negative voltage. (Impulse $100 \mathrm{kV}$ )

に負笔荷の存在が認められるが，これは電子が油分子 に付着して負イオンが形成されることを示している。

固体表面で生ずる沿面放電は正針，負針ともに電子 の衙突電離により開始されるが，正針の場合は電離に より生じた電子は針電極の方向に進み，正イオンは 放電の跡に正表面電荷壳形成し, こ机が放電先端の電 界を大汇する。負針の場合，電子は針々反対方向に進 み, 残された正電荷は先端の電界を弱めるが, 針付近 の電界在強化するので检からの電子の放出が助長さ れ，放電が維持される。この機構は気中放電について 確かめられているが, ${ }^{(3)}$ 油中放電についてはまだ磪か な実験結果が得られていないので, 類推の域を脱しな い。

$\langle 3 \cdot 2\rangle$ 本手法の特徵液体現像液に上る油中放 
電図形の方法を往来用いてきた湜合粉体による方法上 比較吉ると，長所としては，

（1）現像作業が簡単である。

（2）卜ナが微精子のため解像力のすぐれた図形が 得られる。

短所としては，

（3）正，負現像液がとあに黑色のため，色による 極性の識別苏不可能である。

（4）正負現像液在混合すると带雪肪消失するの で，故電により生じる正㧍よび負電荷の分布を同時に 求めることができない。

\section{4. 細满の効果}

证来上り油中沿面放電の問題上して，絶緑物表面に

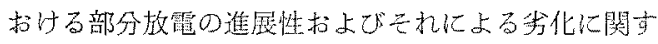
る研究や，フラッシオーバ特性を向上させるくふうが 試みられている。たとえ枯，沿面フラッシオーバ電王 を高める方法として，沿面距離を長くするためス卜り 一マの進む方向に直角にバリヤ設䈯することが考无 られている。

浴面ストリーマが進展する場合は，正傎放電と毛化 先端では電子の䘖突電離が行なわれていると考えられ るので，落者らは絶縁物表面に細いみぞがあると，そ こを通過する電子のエネルギーが変化し，それによっ てフラッシオーバ電压の上昇をあたらすことができる と期待した。

ストリーマ状放電が伸びている状態で，針電極から その珗端までの電圧降下を然視し，ストリーマ先端の 笔眎を考えてみる。しかし，ストリーマ先端の形状を 正確にとらえることができず，その点での電界強度を 求めることが困醮なので，先端での電界とくに䋓縁板 之重直方向牦働々成分を巨視的比みて二つの成分に分 けてみる。(第 5 図参照)

（1）絶縁油之絶縁板との誘電率の差による力

この力は, 絶縁油の誘電摔 $\varepsilon_{1}$, 絶縁板の誘電率を $\varepsilon_{2}$, 電子の電荷を。，電子肪絶緑板表面加ら距離 $a$ だ け離れた絶縁油中にするとすれば，

$$
F=-\frac{1}{4 \pi \varepsilon_{1}} \frac{\varepsilon_{2}-\varepsilon_{1}}{\varepsilon_{2}+\varepsilon_{1}} \frac{e^{2}}{(2 a)^{2}}
$$

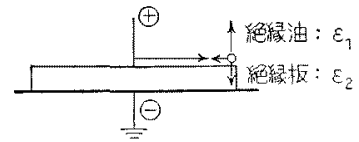

(a) 正極惟 (b) 勇整甠

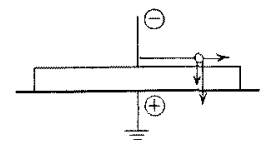

第 5 図 放露先端における重直方向の力

Fig. 5. The forces perpendicular to the insulator at the tip of discharge.
で示される。(5) したがって，通常の絶緑油，絶縁板の 組合せでは $\varepsilon_{2}>\varepsilon_{1}$ であるから，正および負放電にお いて電子を板に引きつけるように作用する。

（2）幾何学的筐界に上る力この力は正針の場 合は電子を上方汉発するように作用し，負針の場合 には電子を下方に引きつけるように作用する。

したがって，正針の場合は(1)項と（2）項の力は反 対方向化作用し, 負針の場合は (1) 項之 (2) 項の力は 上屯に電子を板に吸引するように作用する。

以上のとと加ら針に負霡王学印加した場合，沿面放 電は板に引きつけられつつ進展するが，正放電の場合 はこの力は負の場合より弱いと考えられるので，細溝 の効果に関して極性差のあるととが予想さ机る。

〈4・1〉実験方法および結果上記のととを確加

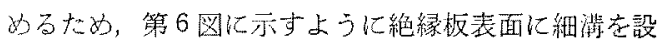
けて沿面放電の進展の樣子を放電図形を用いて調へ た。絶縁板は前述の实験で用いたすの之同じ厚さ（3 $\mathrm{mm})$ のベークライトで，細潭の幅は 1,2 扰よび 5 $\mathrm{mm}$, 澡さはすべて $1 \mathrm{~mm}$ とした。針電極はみぞか ら $5 \mathrm{~mm}$ の位置汇配置した。正抢上び目放管を順現像 した例老第 7 図(a)，(b)に示した。

図形の形状は正負ともみぞのない平板の場合上おお よそ同じであるが，負図形に扰いては放電の幹の部分 はみぞに対し平行に伸びやすい傾向がみられる。(第7 図(b)]

正放電の場合は，みぞに対し直角方向のストリーマ の伸びの長さ（放電図形の最大径）についてははんん ど影響がなく，みぞの縁 (Edge) の効果も活とんど認 められない。しかし，みぞの蝠を大にすると印加電压 肪低い場合には多少影響加古る。

負放電の場合は，沿面ストリーマの進展付対する影 響だけでなく，みぞの緑の㘯果すある。ストリーマが 縁化達する己正の場合のようにみぎを渡らないで， みぞと平行な力向に進展する。

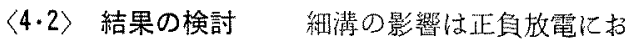
いて著しい極性効果があり，負放電に対する効果が大 きいので，ここでは負放電の場合について考察する。

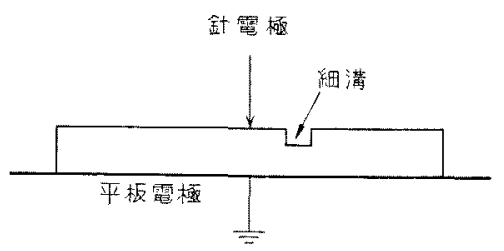

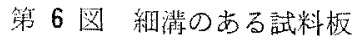

Fis. 6. The sample plate having a slot. 


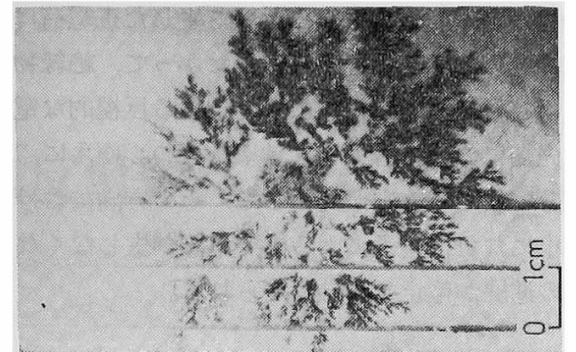

(a) 正極性放電 $(70 \mathrm{kV})$

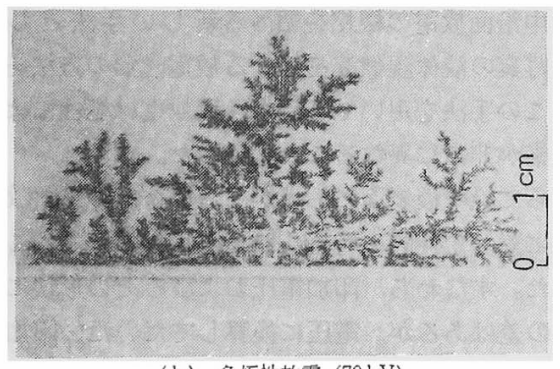

(b) 負極性放電 $(70 \mathrm{kV})$

第 7 図 細瑇偣対する沿面放電の極性効果

Fig. 7. The polarity effect of surface discharge on a slot.

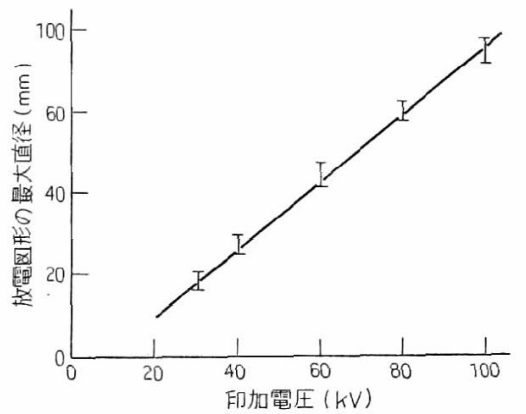

第 8 図 印加電圧之放電図形の伸びの関係

(負極性インパルス)

Fig. 8. Relation between applied voltage and extent of discharge figure. (Negative impulse)

第 8 図は細瑇を設けた試料板と同じ厚さの板を用い て，みぞをつけない場合の印加電圧と図形の最大径の 関係を示している。細潅がある試料板では負放電の進 展はみぞで阻止されるが，みぞと平行なストリーマの 伸びが大となり，放電の広がり面積はみぞがない場合 とほぼ等しくなる。したがって，みぞと平行方向にお けるフラッシオーバ電压が低下することになる。

絶縁板表面にみぞがあると電界のひずみが著しく， かつ静電界の計算をしても，この場合は細溝の効果を 電界強度によって評価するととは困難である。みぞ自

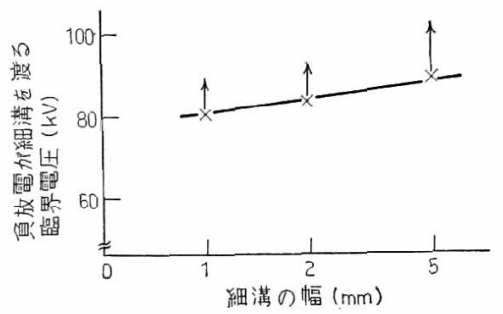

第 9 図 負放電に対する細清の効果

Fig. 9. Effect of slot on the negative discharge.

体のあつ沿面フラッシオーバ上の効果を示したものが 第 9 図である。とれよりみぞの幅の效果がわかる。

次に細溝の効果を沿面距離の面から検討するため, 第 10 図(a)に示すような試料を用い，その上段の面 に針電極を配置してインパルス電压を印加した。正放 電は沿面距離に関係なくストリーマが進展して段をお りるが，負放電は沿面距離の影響を受ける。平板上の 放電図形に抽い，その大きさが，ちょうど第 10 図 (a)の上側の板の面積に相当する電圧を考えておく。 しかるに, 第 10 図( a )の場合, その值よりあ相当高 い印加電圧を加えても，図形が上段のベークライト板 から下段まで進展するととがない。たとえば，沿面距 離が $10 \mathrm{~mm}$ のとき放電が下段の面まで伸びる臨界電 圧は $66.6 \mathrm{kV}$ であり，これ在第 8 図の電圧一伸び特性 より算定すると $31.6 \mathrm{kV}$ だけ過電圧がかけられたこ とになり，印加電生にして約 50\% 增の効果があっ た。負極性ストリーマの進展が停止する例を第 11 図 に示す。

さらに、ストリーマの先端がみぞの縁に達したとき に，みぞの壁面の傾斜角の影響があることが予想され るので，第 10 図(b)のような試料を用いて実験した 結果，傾斜角が小さい上きは放電は壁面を下がって進 展するが，90 度に近づくと壁面を下がるととができ ない。（第 12 図）正放電の場合はやはりこの効果は なく，いずれにしてあ放電は先まで進展する。

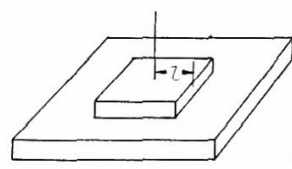

乙：沿面距﨎

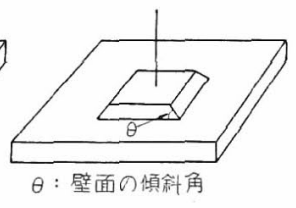

(b) (a) 段のある試料板

(a) The sample plate having a stair (b) 傾斜面のある試料板

(b) The sample plate having inclines. 第 10 図

Fig. 10. 


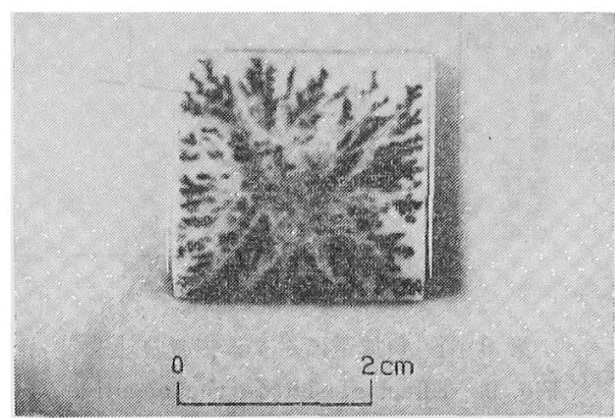

第 11 図負放電住対する進展阻止效果 $(80 \mathrm{kV})$

Fig. 11. Bloking effect on negative discharge.

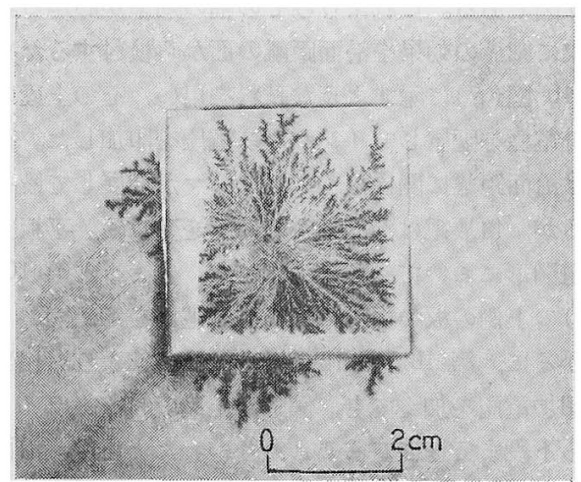

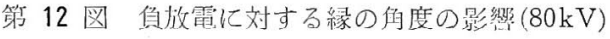

Fig. 12. Influence of the angle of edge on negative discharge.

以上の現象について要約すれば次の上うである。

正極性沿面放電においては，電子の衝乫電離により 生じた正電荷は筀間電荷として作用して先端の電界を 強化するので，細潅の縁端部にストリーマが到達し， その方向が变化しても先端の電界強度はほとんよ゙変化 しない上考えられる。したがって，細渻の効果はほ上 んどなく油中放電が進む。とれに対して負極性放電の
場合は，電子の衝突電離によって生じた正電荷は先端 の電界を弱める作用をする。したがって，絶縁物の材 料㧍よび幾何学的配列によって定まる巨視的な電界が 放電先端においても大きな効果をむつ。ゆえに，細筝 の部分で放電の方向が変化して，その方向における電 界が小になれば電子による衝突電離が生じなくなり, 放電の進展が停上すると考元られる。

\section{5.あとがき}

油中沿面放電の様相を調べる新しい手法として, 電子写真の液体現像液を用いる放電図形の方法を紹介 し，この手法を用いて，油中沿面放電は極性によりそ の機構が非常に異なることを述べた。

さらに絶縁板表面に細满がある場合，特に負放電の 進展に対し定性的に考えられた阻止效果があることを 示した。すなわち，印加電圧およびみぞの形状により 多少の差はあるが，電圧に換算してだいたい印加電圧 の 50\% 増にあたる効果があった。

本論文に述べられた以外の効果については，今後さ らに検討していく予定である。

終わりに，本研究に対し有益なご助言をいただいた 本学の堺 孝夫教授に感謝するとと屯に，実験に協力 された本学学生の川崎 剛(現, 日本電信電話公社), 中野滋章(見，日本鋼管），益子典道(現，日平産業)の 三君に対し謝意を表する。

(昭和 46 年 8 月 21 日受付, 同 47 年 1 月 8 日再受付)

\section{文献}

\begin{tabular}{|c|c|}
\hline (1) & Y. Toriyama: Phys. Rev. 37, 5, 619 (1931) \\
\hline (2) & $\begin{array}{l}\text { Y. Toriyama: Dust Figure of Surface Discharge and its } \\
\text { Application (1961) Kinokuniya, Japan }\end{array}$ \\
\hline (3) & たとえば，小山・室岡：昭46留気学会全大 105 \\
\hline (4) & 井関·倉橋・松浦 - 仲神：昭42電気四学会連大 138 \\
\hline (5) & 竹山：電潑気洪象理諭（昭 31）丸善 \\
\hline (6) & 岸田·传藤·鳥山：炤46雷気学会全大 112 \\
\hline
\end{tabular}

